\title{
Eosinophils and disease pathogenesis
}

\section{Citation}

Akuthota, Praveen, and Peter F. Weller. 2012. Eosinophils and disease pathogenesis. Seminars in Hematology 49, no. 2: 113-119. doi:10.1053/j.seminhematol.2012.01.005.

\section{Published Version}

doi:10.1053/j.seminhematol.2012.01.005

\section{Permanent link}

http://nrs.harvard.edu/urn-3:HUL.InstRepos:27377616

\section{Terms of Use}

This article was downloaded from Harvard University's DASH repository, and is made available under the terms and conditions applicable to Other Posted Material, as set forth at http:// nrs.harvard.edu/urn-3:HUL.InstRepos:dash.current.terms-of-use\#LAA

\section{Share Your Story}

The Harvard community has made this article openly available.

Please share how this access benefits you. Submit a story.

Accessibility 
Published in final edited form as:

Semin Hematol. 2012 April ; 49(2): 113-119. doi:10.1053/j.seminhematol.2012.01.005.

\title{
Eosinophils and Disease Pathogenesis
}

\author{
Praveen Akuthota ${ }^{a, b}$ and Peter F. Weller ${ }^{b, c}$ \\ aDivision of Pulmonary, Critical Care, and Sleep Medicine, Department of Medicine, Beth Israel \\ Deaconess Medical Center, Harvard Medical School, Boston, MA \\ ${ }^{b}$ Division of Allergy and Inflammation, Department of Medicine, Beth Israel Deaconess Medical \\ Center, Harvard Medical School, Boston, MA
}

'Division of Infectious Diseases, Department of Medicine, Beth Israel Deaconess Medical Center, Harvard Medical School, Boston, MA

\begin{abstract}
Eosinophils are granulocytic innate immune cells whose presence is conspicuous in a variety of disease states, including eosinophilic hyperproliferative and infiltrative processes, as well as conditions associated with maladaptive Th2 inflammation. This review discusses the role of eosinophils in disease pathogenesis, including a consideration of relevant eosinophil biology. Eosinophilic disease patterns of tissue infiltration are also detailed, as are candidate mechanisms by which eosinophils cause fibrosis and hypercoagulability and the importance of eosinophils in allergic inflammation. Eosinophils are unique cells in their spectrum of associated disease, with the promise of future discoveries in delineating the manner in which they contribute to disease pathogenesis.
\end{abstract}

Eosinophils are granulocytic innate immune cells that are classically regarded as having a homeostatic role in the defense against helminth parasitic infections. However, their presence is conspicuous in a variety of disease states, including eosinophilic hyperproliferative and infiltrative processes, as well as conditions associated with maladaptive Th2 inflammation. The mechanisms by which eosinophils cause disease have not been fully elucidated, but accumulated observations and evidence have allowed for improved understanding of the interaction of eosinophil biology with disease pathogenesis and of patterns of disease caused by blood and tissue eosinophilia. This review will discuss the role of eosinophils in disease pathogenesis, including a consideration of eosinophil biology, with a focus on mechanisms of eosinophilia and mechanisms of eosinophil activation. In addition, the spectrum of eosinophilic infiltration, the contribution of eosinophils to tissue fibrosis and to hypercoagulability, and the importance of eosinophils in allergic inflammation will be detailed.

\section{Eosinophil Biology}

Blood eosinophilia occurs in response to soluble factors, namely, the cytokines interleukin (IL)-5, granulocyte-macrophage colony-stimulating factor (GM-CSF), and IL-3 (Figure 1). IL-5 has been well established to be specific and essential to eosinophils, having a central role in promoting eosinophil differentiation, ${ }^{1,2}$ proliferation, ${ }^{3}$ trafficking, ${ }^{4}$ and survival. ${ }^{5}$

\footnotetext{
(C) 2012 Elsevier Inc. All rights reserved.

Address correspondence to Peter F. Weller, MD, Department of Medicine, Beth Israel Deaconess Medical Center, CLS 943, 330 Brookline Aven, Boston, MA 02215, USA. pweller@bidmc.harvard.edu.

The authors have no financial disclosures or conflicts of interest relevant to the content of this article.
} 
IL-5 was discovered as a cytokine that could specifically promote eosinophil differentiation from bone marrow precursor cells. ${ }^{1}$ The priming of eosinophils with IL-5 facilitates their chemotaxis to eosinophil chemoattractants and is itself a potent eosinophil chemoattractant. ${ }^{4,5}$ Eosinophils stimulated with IL-5 have extended survival when cultured in vitro. ${ }^{5}$ Exposure to IL-5 has also been shown to facilitate degranulation and release of cationic cytotoxic mediators from eosinophils. ${ }^{6}$ Human eosinophils cultured with IL-5 release eosinophil-derived neurotoxin (EDN), eosinophil peroxidase (EPO), and eosinophil cationic protein (ECP) and become hypodense due to release of these granule contents. ${ }^{6}$ Several disease processes characterized by hypereosinophilia have been shown to be associated with elevated production of IL-5, including hypereosinophilic syndrome (HES), ${ }^{7}$ asthma, ${ }^{8}$ Churg-Strauss syndrome (CSS),${ }^{9}$ and eosinophilic esophagitis (EoE). ${ }^{10}$ The association of IL-5 elevation with these disorders, in concert with the known importance of IL-5 to eosinophils, has made neutralization of IL-5 an attractive therapeutic target. Monoclonal antibody against IL-5 has been demonstrated in human trials to be effective in the treatment of HES, ${ }^{11}$ eosinophilic asthma, ${ }^{12,13}$ and CSS. ${ }^{14}$ Treatment of HES patients negative for the FIP1L1-PDGFRA gene rearrangement with the anti-IL-5 antibody mepolizumab (GlaxoSmithKline, Brentford, UK) reduced eosinophil counts and allowed for substantial tapering of corticosteroids in a randomized, placebo-controlled clinical trial. ${ }^{11}$ Use of mepolizumab was effective in reducing asthma exacerbations in two randomized controlled trials of patients with asthma selected on the basis of sputum eosinophilia. ${ }^{12,13}$ An open-label study of mepolizumab in CSS similarly resulted in both tapering of corticosteroids and reduction of disease exacerbation. ${ }^{14}$

Both GM-CSF and IL-3 also have potent effects on eosinophils, though unlike IL-5 their activity is not specific to eosinophils alone nor is their presence essential to eosinophil differentiation and proliferation like that of IL-5. The receptors for IL-5, GM-CSF, and IL-3 all share a common $\beta$ subunit that is responsible for signaling activity, explaining some of the overlapping effects of these cytokines on eosinophils. ${ }^{15-17}$ All three cytokines have the ability to promote eosinophil survival in low concentrations. ${ }^{17}$ In fact, antagonism of binding with antibody against the binding site on the $\beta$ subunit can inhibit the activity of all three cytokines. ${ }^{18}$ It has been suggested that among this group of cytokines, GM-CSF has the greatest effect on eosinophil survival. ${ }^{19}$ This assertion comes from the observation that the bronchoalveolar lavage fluid from patients with asthma has the ability to promote eosinophil survival that is neutralized to the greatest extent by antibody against GM-CSF, compared to antibody against IL-5 or IL-3. ${ }^{19}$ In addition to enhanced survival, exposure to IL-3 also activates eosinophils, making them more hypodense, augmenting lipid mediator release, and facilitating toxicity to helminths. ${ }^{20} \mathrm{GM}$-CSF activates eosinophils in a wideranging manner, resulting in augmented secretion of granule contents, ${ }^{21}$ augmented adhesion, ${ }^{22}$ increased vascular endothelial growth factor (VEGF) secretion, ${ }^{23}$ and upregulation of major histocompatibility complex (MHC) class II. ${ }^{24}$ GM-CSF and IL-3 exposure primes eosinophils to secrete ECP in response to stimulation with the complement fragment $\mathrm{C} 3 \mathrm{~b} .{ }^{21} \mathrm{GM}-\mathrm{CSF}-$ stimulated eosinophils have improved binding to endothelium in a very late antigen-4 (VLA-4)-dependent fashion compared to unstimulated eosinophils. ${ }^{22}$ As discussed below, eosinophils have been found to have antigen-presenting properties. GM-CSF is key to the antigen-presenting activity of eosinophils, as it is necessary for the expression of MHC class II and obligate co-stimulatory surface proteins. ${ }^{24,25}$ Eosinophils are also themselves capable of producing GM-CSF and IL-3 (as well as IL-5), resulting in autocrine effects on eosinophil survival and function. ${ }^{26}$

Eosinophils become activated in response to a variety of stimuli, contributing to their ability to infiltrate tissues and participate in disease pathogenesis. Specifically, eosinophils may demonstrate increased secretion of granule contents, release of cytokines, respiratory burst, chemotaxis, release of lipid mediators, and cytoskeletal rearrangements with shape change 
when activated. ${ }^{27,28}$ Though a range of soluble factors can activate eosinophils, one prime example is the response of eosinophils to stimulation via the eotaxin receptor, C-C chemokine receptor-3 (CCR3), by the eotaxins. ${ }^{27}$ Interestingly, treatment of HES patients with mepolizumab results in the reduced ability of eosinophils to become activated ex vivo as measured by shape change in response to CCR3 stimulation by eotaxin- $-1,-2$, and $-3 .^{29}$ MHC class II, co-stimulatory molecules, and adhesion molecules are upregulated in various disease states in which eosinophils are activated. ${ }^{25} \mathrm{In}$ asthma, complete remission of disease has been differentiated from active disease by reversal of eosinophil activation, as assayed by the release of cationic granule proteins. ${ }^{30}$

\section{Disease Pathogenesis}

The spectrum of eosinophilic diseases is broad, with the potential to involve all organ systems. It is important to note the tissue eosinophilia may occur with or without blood eosinophilia. Similarly, the presence of blood eosinophilia does not necessarily portend the presence of tissue eosinophilia. Though the mechanisms by which tissue eosinophilia occurs and cause disease still remain incompletely understood, some overarching themes can be applied to eosinophilic disease pathogenesis.

\section{Tissue Infiltration}

While the presence of a modest number of eosinophils may be normal in some tissues, such as the gastrointestinal tract, the excessive infiltration of eosinophils into tissues is in and of itself pathologic and potentially representative of local or systemic disease. Eosinophilic inflammation is a central component of a distinct set of diseases involving the skin, lungs, heart, gastrointestinal tract, kidneys, sinuses, and nervous system, with or without other systemic manifestations (Figure 2).

Eosinophils are commonly found infiltrating skin lesions in atopic dermatitis, ${ }^{31}$ as well as in blistering skin diseases and urticarial disorders. ${ }^{32}$ Eosinophilia may affect all tissue layers of the skin, with eosinophilic cellulitis, fasciitis, and panniculitis all having been described. ${ }^{33-35}$ Blood eosinophilia occurs with flares of episodic angioedema with eosinophilia, also known as Gleich's syndrome. ${ }^{36}$

The lungs are a common site for pathologic eosinophilic infiltration, most commonly in allergic asthma. As discussed above, the specific targeting of eosinophils via neutralization of IL-5 in asthma has proven to be a successful therapy for selected patients in clinical trials. The pulmonary parenchyma is commonly involved in hypereosinophilic syndrome, with $40 \%$ of patients demonstrating pulmonary involvement. ${ }^{7}$ While cough and eosinophilic pulmonary infiltrates are the most common pulmonary manifestations, fibrosis of the lung parenchyma may occur as well. ${ }^{7}$ Similarly, though CSS is a systemic process characterized by eosinophilic vasculitis, patients often present with eosinophilia in the context of asthmatic symptoms coupled with pulmonary infiltrates and sinus abnormalities. ${ }^{37}$ The eosinophilic pneumonias, both acute and chronic, provide illustrative examples of the potentially pathogenic nature eosinophilic infiltration. ${ }^{37}$ Acute eosinophilic pneumonia causes respiratory failure resembling the acute respiratory distress syndrome, and chronic eosinophilic pneumonia manifests itself in dyspnea and hypoxemia. Allergic bronchopulmonary aspergillosis, drug reactions, and parasitic infections are also associated with pathologic eosinophilic lung inflammation. ${ }^{37}$

The infiltration of eosinophils into the heart in HES, tropical eosinophilia, and several other systemic eosinophilic disorders has downstream effects, starting with necrosis and thrombosis, but culminating in fibrosis. ${ }^{7}$ A more detailed discussion of the relationship of 
tissue eosinophilia with fibrosis follows below. Cardiac involvement of CSS may include coronary vasculitis and myocardial damage. ${ }^{37}$

EoE is emerging as an increasingly recognized gastrointestinal eosinophilic infiltrative disease. The inflammatory processes leading to infiltration of esophagus have significant overlap with allergic disease, with an important Th2 inflammatory component. ${ }^{38}$

Eosinophilic inflammation may also occur in other parts of the gastrointestinal tract, causing gastroenteritis or contributing to hepatobiliary disease.

Infiltration of nervous structures can occur with CSS and HES. ${ }^{7,37}$ Neurologic dysfunction in HES can occur due to direct CNS dysfunction and peripheral neuropathy, or can be due to central thromboembolic phenomena directly related to eosinophilia. ${ }^{7}$

\section{Fibrosis}

Tissue eosinophilia may result in local fibrosis, particularly in the heart, the airway, and the skin. It has been suggested that eosinophils and deposition of eosinophilic granule contents may be involved in a wide range of inflammatory fibrotic processes ${ }^{39}$ Eosinophils have been noted in several in vitro studies to be profibrogenic. Pincus et al observed that extracts from both eosinophils and eosinophil granule preparations had the ability to stimulate DNA synthesis in human fibroblasts. ${ }^{40}$ Similarly, sonicated eosinophils have the ability to stimulate lung fibroblast proliferation, as well as collagen production from dermal fibroblasts. ${ }^{41}$ The stimulatory effect of eosinophils on fibroblasts is dependent on the profibrotic cytokine-transforming growth factor- $\beta$ (TGF- $\beta$ ), as antibody neutralization of TGF$\beta$ partially reverses these effects. ${ }^{41}$ Eosinophils from patients with hypereosinophilia have increased expression of mRNA for TGF- $\beta$ compared to eosinophils from normal donors, ${ }^{42}$ supporting the idea that eosinophils are abnormally activated in disease. Conditioned media from cultured eosinophils have been demonstrated to stimulate fibroblast replication as well. ${ }^{43}$ Human eosinophils cultured with fibroblasts augment the contraction of threedimensional collagen matrices. ${ }^{44} \mathrm{ECP}$ itself has been observed to have the same effect on collagen matrices, as well as stimulating TGF- $\beta$ release from fibroblasts. ${ }^{44,45}$ Other data suggest that IL- $1 \beta$ secretion by eosinophils is an important mediator in promoting a fibrogenic phenotype by fibroblasts. ${ }^{46}$ Interestingly, HES patients with elevated serum tryptase levels are more likely to develop end-organ fibrosis. ${ }^{47}$ These data, in concert with in vitro data in the literature showing significant cross-talk between eosinophils and mast cells, ${ }^{48}$ suggest that mast cells may have an important role in eosinophil-mediated fibrosis.

Cardiac fibrosis has long been recognized as a potential complication of hypereosinophilia, whether related to parasitic disease, idiopathic HES, malignancy, CSS, or other causes. ${ }^{7,49,50}$ It is a significant source of morbidity in HES and CSS. ${ }^{7,37}$ Of note, cardiac fibrosis is not only characteristic of the chronic eosinophilic leukemia variant of $\mathrm{HES},{ }^{51}$ but common to a wide-range of eosinophilic disorders. In tropical eosinophilia and HES, cardiac fibrosis is a late manifestation of the disease, occurring after progression through the earlier stages of cardiac necrosis and thrombosis. ${ }^{7}$ The development of cardiac fibrosis in eosinophilic disorders is unpredictable with unclear etiology beyond that described by the above in vitro data. It is likely that the activation state of eosinophils contributes to their ability to cause tissue fibrosis. A commentary in The Lancet in 1977 presciently noted that there may be "benign" and "sinister" eosinophils that explain the differential development of cardiac fibrosis. 52

A correlation between lung eosinophilia and idiopathic pulmonary fibrosis (IPF) has been observed, with elevated bronchoalveolar lavage eosinophil counts and ECP levels found in IPF and with more rapid progression of disease ${ }^{53,54}$ Elevated eosinophil counts and ECP levels can be found in induced sputum of patients with IPF as well. ${ }^{55}$ In bleomycin murine 
models of pulmonary fibrosis, hypereosinophilia induced by transgenic overexpression of IL-5 increases the extent of lung injury.

Asthma is characterized by subepithelial fibrosis, and ample evidence exists that eosinophils have a significant pathologic role in promoting airways fibrosis. ${ }^{57}$ Eosinophils have been found in airway biopsies from patients with asthma to be a major source of TGF- $\beta$, as detected by both mRNA and protein expression. ${ }^{58}$ TGF- $\beta$ is produced by airway eosinophils after allergen challenge to asthmatic subjects. ${ }^{59}$ The TGF- $\beta 2$ isoform has specifically been found to be associated with severe eosinophilic asthma. ${ }^{60}$ Murine models of asthma show that eosinophils recruited to airways produce TGF- $\beta$, and that depletion of eosinophils either through IL-5 receptor gene knockout or administration of anti-IL-5 antibody prevents subepithelial and peribronchial fibrosis. ${ }^{61}$ Similarly, data from eosinophil deficient $\Delta \mathrm{dbl}$ GATA mice support the role of eosinophils in fibrosis. $\Delta \mathrm{dbl}$ GATA mice are deficient in eosinophils in a selective manner due to the deletion of a high-affinity binding site in the GATA-1 promoter, and these animals show reduced airway extracellular matrix deposition upon allergen sensitization and airway challenge. ${ }^{62}$ One of the preliminary studies of the use of anti-IL-5 therapy in human subjects with asthma described reduced airway fibrosis with a decrease in the subepithelial deposition of extracellular matrix proteins. ${ }^{63}$

Subepithelial fibrosis is also characteristic of EoE. ${ }^{64}$ The fibrosis that occurs in EoE has significant clinical consequences, contributing to dysphagia and strictures. ${ }^{64}$ Aceves et al found increased subepithelial fibrosis in biopsy specimens from pediatric patients with EoE, and they also noted that many of the TGF- $\beta$-expressing cells were eosinophils. ${ }^{65}$

\section{Hypercoagulability}

Eosinophilia, particularly in the context of HES, has been recognized to contribute to disease pathogenesis through promotion of hypercoagulability. ${ }^{50}$ Several case reports have described the occurrence of several varieties of thrombosis in HES, including deep venous thrombosis and cutaneous infarction, ${ }^{66}$ superficial venous thrombophlebitis, ${ }^{67}$ and thrombotic microangipathy. ${ }^{68}$ Ogbogu et al have described in detail the potential for HES to cause intracardiac thrombosis. ${ }^{50}$ These investigators suggest that up to a quarter of HES patients develop thrombotic complications, based on compilation of case series and case reports. ${ }^{50}$ Diffuse systemic thrombophlebitis in the context of hypereosinophilia has been described as well.

Patients with eosinophilia of various etiologies have been observed to have increased levels of fibrinogen, fibrin degradation products, and platelets compared to control subjects. ${ }^{70}$ From a mechanistic perspective, Venge and colleagues noted in 1977 that ECP had the ability to promote the coagulation of plasma in a factor XII-dependent fashion. ${ }^{71}$ Other cationic eosinophil granule proteins, such as MBP and EPO, can activate platelets in vitro. ${ }^{72}$ In addition, MBP has the ability to inhibit the activity of both endothelial cell surface thrombomodulin and soluble thrombomodulin in generating the anticoagulant activated protein C. ${ }^{73}$ EPO, as well as protein extract from lysed eosinophil granules, is able to inhibit the anti-coagulant effect of the mast cell tryptase/heparin complex. ${ }^{74}$ EPO itself acts as a procoagulant and counters the anticoagulant activity of heparin. ${ }^{74}$ The oxidization product of thiocyanate by EPO is a potent inducer of tissue factor activity by human umbilical vein endothelial cells. ${ }^{75}$ Peripheral eosinophils are themselves a significant source of tissue factor, and stimulation of eosinophils with GM-CSF and platelet-activating factor causes translocation of tissue factor to the eosinophil cell surface. ${ }^{76}$ Lysed stimulated eosinophils cause the formation of factor $\mathrm{Xa}$ from factor $\mathrm{X}$ when incubated with coagulation factor concentrate; this effect is dependent on tissue factor, given the observed inhibition with addition of neutralizing antibody to tissue factor. ${ }^{76}$ 


\section{Allergic Mechanisms}

The substantial contributions of eosinophils to allergic mechanisms of disease have been discussed in prior reviews. ${ }^{25,77}$ The presence of eosinophils is a hallmark of allergic inflammation. As described earlier, the generation of IL-5 in Th2 inflammation promotes eosinophilic infiltration and survival. Eosinophils are a source of lipid mediators of allergic inflammation (including leukotriene $\mathrm{C}_{4}$ ), as well effectors of cytotoxic activity through the release of their cationic granule contents. ${ }^{78}$ Of particular note is the development of a robust literature demonstrating that eosinophils have diverse immunoregulatory functions that are integral to allergic inflammation. ${ }^{25}$ Eosinophils possess pools of preformed cytokines that they are able to rapidly mobilize and differentially secrete, allowing them to participate intimately in modulation of Th2 and Th1 inflamma-tion. ${ }^{79}$ Recent evidence suggests that distinct eosinophil subpopulations may exist that express differential cytokine and chemokines in dermatologic disorders, ${ }^{80}$ and circulating eosinophil subpopulations characterized by differential surface marker expression differentiate between EoE, inflammatory bowel disease, and airway allergy. ${ }^{81}$ They are able to function as antigenpresenting cells as well, which may be important for perpetuation of allergic inflammation. ${ }^{82}$ Recent data suggest that eosinophils also contribute to bronchoconstriction in allergic airway disease through stimulation of nerves to airway smooth muscle, ${ }^{83}$ and that eosinophils may stimulate neuronal growth in atopic dermatitis. ${ }^{84}$

\section{Conclusions}

Ehrlich first identified the eosinophilic leukocyte almost 140 years ago, but a full understanding of the mechanisms of eosinophilic disease pathogenesis remains elusive. However, a series of findings over the last 30 years has allowed for a better appreciation of the importance of cytokines and chemokines, particularly IL-5, GM-CSF, and the eotaxins, to the promotion of eosinophilia and eosinophilic disease. Neutralization of IL-5 with monoclonal antibody has become a promising potential therapy for a wide-spectrum of eosinophilic diseases, while providing important mechanistic insights into eosinophilic disease. Accumulated case series and case reports of end-organ eosinophilic infiltration have facilitated improved categorization of eosinophilic disease patterns. Candidate mechanisms by which eosinophils cause fibrosis and hypercoagulability have been elucidated, as has a more sophisticated understanding of the role of eosinophils in allergic inflammation. Eosinophils are clearly unique cells in their spectrum of associated disease, with the promise of future discoveries in delineating the manner in which they contribute to disease pathogenesis.

\section{Acknowledgments}

This work was supported in part by National Institutes of Health Grants No. R01 AI051645 and R01/R37 AI020241 (to P.F.W.).

\section{References}

1. Sanderson CJ, Warren DJ, Strath M. Identification of a lymphokine that stimulates eosinophil differentiation in vitro. Its relationship to interleukin 3, and functional properties of eosinophils produced in cultures. J Exp Med. 1985; 162:60-74. [PubMed: 3925072]

2. Clutterbuck EJ, Sanderson CJ. Human eosinophil hematopoiesis studied in vitro by means of murine eosinophil differentiation factor (IL5): production of functionally active eosinophils from normal human bone marrow. Blood. 1988; 71:646-51. [PubMed: 3257886]

3. Yamaguchi Y, Suda T, Suda J, et al. Purified interleukin 5 supports the terminal differentiation and proliferation of murine eosinophilic precursors. J Exp Med. 1988; 167:43-56. [PubMed: 3257253] 
4. Warringa RA, Schweizer RC, Maikoe T, Kuijper PH, Bruijnzeel PL, Koendermann L. Modulation of eosinophil chemotaxis by interleukin-5. Am J Respir Cell Mol Biol. 1992; 7:631-6. [PubMed: 1449809]

5. Yamaguchi Y, Hayashi Y, Sugama Y, et al. Highly purified murine interleukin 5 (IL-5) stimulates eosinophil function and prolongs in vitro survival. IL-5 as an eosinophil chemotactic factor. J Exp Med. 1988; 167:1737-42. [PubMed: 2835420]

6. Kita H, Weiler DA, Abu-Ghazaleh R, Sanderson CJ, Gleich GJ. Release of granule proteins from eosinophils cultured with IL-5. J Immunol. 1992; 149:629-35. [PubMed: 1624806]

7. Weller PF, Bubley GJ. The idiopathic hypereosinophilic syndrome. Blood. 1994; 83:2759-79. [PubMed: 8180373]

8. Hamid Q, Azzawi M, Ying S, et al. Expression of mRNA for interleukin-5 in mucosal bronchial biopsies from asthma. J Clin Invest. 1991; 87:1541-6. [PubMed: 2022726]

9. Hellmich B, Csernok E, Gross WL. Proinflammatory cytokines and autoimmunity in Churg-Strauss syndrome. Ann N Y Acad Sci. 2005; 1051:121-31. [PubMed: 16126951]

10. Assa'ad AH, Gupta SK, Collins MH, et al. An antibody against IL-5 reduces numbers of esophageal intraepithelial eosinophils in children with eosinophilic esophagitis. Gastroenterology. 2011; 141:1593-604. [PubMed: 21835135]

11. Rothenberg ME, Klion AD, Roufosse FE, et al. Treatment of patients with the hypereosinophilic syndrome with mepolizumab. N Engl J Med. 2008; 358:1215-28. [PubMed: 18344568]

12. Haldar P, Brightling CE, Hargadon B, et al. Mepolizumab and exacerbations of refractory eosinophilic asthma. N Engl J Med. 2009; 360:973-84. [PubMed: 19264686]

13. Nair P, Pizzichini MM, Kjarsgaard M, et al. Mepolizumab for prednisone-dependent asthma with sputum eosinophilia. N Engl J Med. 2009; 360:985-93. [PubMed: 19264687]

14. Kim S, Marigowda G, Oren E, Israel E, Wechsler ME. Mepolizumab as a steroid-sparing treatment option in patients with Churg-Strauss syndrome. J Allergy Clin Immunol. 2011; 125:1336-43. [PubMed: 20513524]

15. Kitamura T, Sato N, Arai K, Miyajima A. Expression cloning of the human IL-3 receptor cDNA reveals a shared beta subunit for the human IL-3 and GM-CSF receptors. Cell. 1991; 66:1165-74. [PubMed: 1833064]

16. Tavernier J, Devos R, Cornelis S, et al. A human high affinity interleukin-5 receptor (IL5R) is composed of an IL5-specific alpha chain and a beta chain shared with the receptor for GM-CSF. Cell. 1991; 66:1175-84. [PubMed: 1833065]

17. Tai PC, Sun L, Spry CJ. Effects of IL-5, granulocyte/macrophage colony-stimulating factor (GMCSF) and IL-3 on the survival of human blood eosinophils in vitro. Clin Exp Immunol. 1991; 85:312-6. [PubMed: 1864012]

18. Sun Q, Jones K, McClure B, et al. Simultaneous antagonism of interleukin-5, granulocytemacrophage colony-stimulating factor, and interleukin-3 stimulation of human eosinophils by targetting the common cytokine binding site of their receptors. Blood. 1999; 94:1943-51. [PubMed: 10477723]

19. Park CS, Choi YS, Ki SY, et al. Granulocyte macrophage colony-stimulating factor is the main cytokine enhancing survival of eosinophils in asthmatic airways. Eur Respir J. 1998; 12:872-8. [PubMed: 9817161]

20. Rothenberg ME, Owen WF Jr, Silberstein DS, et al. Human eosinophils have prolonged survival, enhanced functional properties, and become hypodense when exposed to human interleukin 3. J Clin Invest. 1988; 81:1986-92. [PubMed: 3133397]

21. Tai PC, Spry CJ. The effects of recombinant granulocyte-macrophage colony-stimulating factor (GM-CSF) and interleukin-3 on the secretory capacity of human blood eosinophils. Clin Exp Immunol. 1990; 80:426-34. [PubMed: 2197048]

22. Sung KL, Li Y, Elices M, Gang J, Sriramarao P, Broide DH. Granulocyte-macrophage colonystimulating factor regulates the functional adhesive state of very late antigen-4 expressed by eosinophils. J Immunol. 1997; 158:919-27. [PubMed: 8993012]

23. Horiuchi T, Weller PF. Expression of vascular endothelial growth factor by human eosinophils: upregulation by granulocyte macrophage colony-stimulating factor and interleukin-5. Am J Respir Cell Mol Biol. 1997; 17:70-7. [PubMed: 9224211] 
24. Lucey DR, Nicholson-Weller A, Weller PF. Mature human eosinophils have the capacity to express HLA-DR. Proc Natl Acad Sci U S A. 1989; 86:1348-51. [PubMed: 2919183]

25. Akuthota P, Wang HB, Spencer LA, Weller PF. Immuno-regulatory roles of eosinophils: a new look at a familiar cell. Clin Exp Allergy. 2008; 38:1254-63. [PubMed: 18727793]

26. Kita H, Ohnishi T, Okubo Y, Weiler D, Abrams JS, Gleich GJ. Granulocyte/macrophage colonystimulating factor and interleukin 3 release from human peripheral blood eosinophils and neutrophils. J Exp Med. 1991; 174:745-8. [PubMed: 1875171]

27. Bandeira-Melo C, Herbst A, Weller PF. Eotaxins. Contributing to the diversity of eosinophil recruitment and activation. Am J Respir Cell Mol Biol. 2001; 24:653-7. [PubMed: 11415928]

28. Adamko D, Lacy P, Moqbel R. Mechanisms of eosinophil recruitment and activation. Curr Allergy Asthma Rep. 2002; 2:107-16. [PubMed: 11892090]

29. Stein ML, Villanueva JM, Buckmeier BK, et al. Anti-IL-5 (mepolizumab) therapy reduces eosinophil activation ex vivo and increases IL-5 and IL-5 receptor levels. J Allergy Clin Immunol. 2008; 121:1473-83. [PubMed: 18410960]

30. Broekema M, Timens W, Vonk JM, et al. Persisting remodeling and less airway wall eosinophil activation in complete remission of asthma. Am J Respir Crit Care Med. 2011; 183:310-6. [PubMed: 20813885]

31. Leiferman KM. Eosinophils in atopic dermatitis. J Allergy Clin Immunol. 1994; 94:1310-7. [PubMed: 7798571]

32. Simon D, Wardlaw A, Rothenberg ME. Organ-specific eosinophilic disorders of the skin, lung, and gastrointestinal tract. J Allergy Clin Immunol. 2010; 126:3-13. [PubMed: 20392477]

33. Adame J, Cohen PR. Eosinophilic panniculitis: diagnostic considerations and evaluation. J Am Acad Dermatol. 1996; 34:229-34. [PubMed: 8642087]

34. Caputo R, Marzano AV, Vezzoli P, Lunardon L. Wells syndrome in adults and children: a report of 19 cases. Arch Dermatol. 2006; 142:1157-61. [PubMed: 16983003]

35. Doyle JA, Ginsburg WW. Eosinophilic fasciitis. Med Clin North Am. 1989; 73:1157-66. [PubMed: 2671538]

36. Gleich GJ, Schroeter AL, Marcoux JP, Sachs MI, O'Connell EJ, Kohler PF. Episodic angioedema associated with eosinophilia. N Engl J Med. 1984; 310:1621-6. [PubMed: 6727934]

37. Wechsler ME. Pulmonary eosinophilic syndromes. Immunol Allergy Clin North Am. 2007; 27:477-92. [PubMed: 17868860]

38. Liacouras CA, Furuta GT, Hirano I, et al. Eosinophilic esophagitis: updated consensus recommendations for children and adults. J Allergy Clin Immunol. 2011; 128:3-20. [PubMed: 21477849]

39. Noguchi H, Kephart GM, Colby TV, Gleich GJ. Tissue eosinophilia and eosinophil degranulation in syndromes associated with fibrosis. Am J Pathol. 1992; 140:521-8. [PubMed: 1739138]

40. Pincus SH, Ramesh KS, Wyler DJ. Eosinophils stimulate fibroblast DNA synthesis. Blood. 1987; 70:572-4. [PubMed: 3607289]

41. Levi-Schaffer F, Garbuzenko E, Rubin A, et al. Human eosinophils regulate human lung- and skinderived fibroblast properties in vitro: a role for transforming growth factor beta (TGF-beta). Proc Natl Acad Sci U S A. 1999; 96:9660-5. [PubMed: 10449750]

42. Wong DT, Elovic A, Matossian K, et al. Eosinophils from patients with blood eosinophilia express transforming growth factor beta 1. Blood. 1991; 78:2702-7. [PubMed: 1726708]

43. Shock A, Rabe KF, Dent G, et al. Eosinophils adhere to and stimulate replication of lung fibroblasts 'in vitro'. Clin Exp Immunol. 1991; 86:185-90. [PubMed: 1914231]

44. Zagai U, Skold CM, Trulson A, Venge P, Lundahl J. The effect of eosinophils on collagen gel contraction and implications for tissue remodelling. Clin Exp Immunol. 2004; 135:427-33. [PubMed: 15008974]

45. Zagai U, Dadfar E, Lundahl J, Venge P, Skold CM. Eosinophil cationic protein stimulates TGFbeta1 release by human lung fibroblasts in vitro. Inflammation. 2007; 30:153-60. [PubMed: 17587163] 
46. Gomes I, Mathur SK, Espenshade BM, Mori Y, Varga J, Ackerman SJ. Eosinophil-fibroblast interactions induce fibroblast IL-6 secretion and extracellular matrix gene expression: implications in fibrogenesis. J Allergy Clin Immunol. 2005; 116:796-804. [PubMed: 16210053]

47. Klion AD, Noel P, Akin C, et al. Elevated serum tryptase levels identify a subset of patients with a myeloproliferative variant of idiopathic hypereosinophilic syndrome associated with tissue fibrosis, poor prognosis, and imatinib responsiveness. Blood. 2003; 101:4660-6. [PubMed: 12676775]

48. Levi-Schaffer F, Weg VB. Mast cells, eosinophils and fibrosis. Clin Exp Allergy. 1997; 27(Suppl 1):64-70. [PubMed: 9179448]

49. Patel AK, D'Arbela PG, Somers K. Endomyocardial fibrosis and eosinophilia. Br Heart J. 1977; 39:238-41. [PubMed: 849383]

50. Ogbogu PU, Rosing DR, Horne MK 3rd. Cardiovascular manifestations of hypereosinophilic syndromes. Immunol Allergy Clin North Am. 2007; 27:457-75. [PubMed: 17868859]

51. Bain BJ, Fletcher SH. Chronic eosinophilic leukemias and the myeloproliferative variant of the hypereosinophilic syndrome. Immunol Allergy Clin North Am. 2007; 27:377-88. [PubMed: 17868855]

52. Sinister eosinophils and the heart. Lancet. 1977; 1:943. [PubMed: 67397]

53. Hallgren R, Bjermer L, Lundgren R, Venge P. The eosinophil component of the alveolitis in idiopathic pulmonary fibrosis. Signs of eosinophil activation in the lung are related to impaired lung function. Am Rev Respir Dis. 1989; 139:373-7. [PubMed: 2536526]

54. Fujimoto K, Kubo K, Yamaguchi S, Honda T, Matsuzawa Y. Eosinophil activation in patients with pulmonary fibrosis. Chest. 1995; 108:48-54. [PubMed: 7606990]

55. Birring SS, Parker D, McKenna S, et al. Sputum eosinophilia in idiopathic pulmonary fibrosis. Inflamm Res. 2005; 54:51-6. [PubMed: 15750711]

56. Huaux F, Liu T, McGarry B, Ullenbruch M, Xing Z, Phan SH. Eosinophils and T lymphocytes possess distinct roles in bleomycin-induced lung injury and fibrosis. J Immunol. 2003; 171:547081. [PubMed: 14607953]

57. Aceves SS, Broide DH. Airway fibrosis and angiogenesis due to eosinophil trafficking in chronic asthma. Curr Mol Med. 2008; 8:350-8. [PubMed: 18691061]

58. Minshall EM, Leung DY, Martin RJ, et al. Eosinophil-associated TGF-beta1 mRNA expression and airways fibrosis in bronchial asthma. Am J Respir Cell Mol Biol. 1997; 17:326-33. [PubMed: 9308919]

59. Torrego A, Hew M, Oates T, Sukkar M, Fan Chung K. Expression and activation of TGF-beta isoforms in acute allergen-induced remodelling in asthma. Thorax. 2007; 62:307-13. [PubMed: 17251317]

60. Balzar S, Chu HW, Silkoff P, et al. Increased TGF-beta2 in severe asthma with eosinophilia. J Allergy Clin Immunol. 2005; 115:110-7. [PubMed: 15637555]

61. Tanaka H, Komai M, Nagao K, et al. Role of interleukin-5 and eosinophils in allergen-induced airway remodeling in mice. Am J Respir Cell Mol Biol. 2004; 31:62-8. [PubMed: 14975941]

62. Humbles AA, Lloyd CM, McMillan SJ, et al. A critical role for eosinophils in allergic airways remodeling. Science. 2004; 305:1776-9. [PubMed: 15375268]

63. Flood-Page P, Menzies-Gow A, Phipps S, et al. Anti-IL-5 treatment reduces deposition of ECM proteins in the bronchial subepithelial basement membrane of mild atopic asthmatics. J Clin Invest. 2003; 112:1029-36. [PubMed: 14523040]

64. Aceves SS, Ackerman SJ. Relationships between eosinophilic inflammation, tissue remodeling, and fibrosis in eosinophilic esophagitis. Immunol Allergy Clin North Am. 2009; 29:197-211. [PubMed: 19141355]

65. Aceves SS, Newbury RO, Dohil R, Bastian JF, Broide DH. Esophageal remodeling in pediatric eosinophilic esophagitis. J Allergy Clin Immunol. 2007; 119:206-12. [PubMed: 17208603]

66. Narayan S, Ezughah F, Standen GR, Pawade J, Kennedy CT. Idiopathic hypereosinophilic syndrome associated with cutaneous infarction and deep venous thrombosis. Br J Dermatol. 2003; 148:817-20. [PubMed: 12752146] 
67. Terrier B, Piette AM, Kerob D, et al. Superficial venous thrombophlebitis as the initial manifestation of hypereosinophilic syndrome: study of the first 3 cases. Arch Dermatol. 2006; 142:1606-10. [PubMed: 17178987]

68. Liapis H, Ho AK, Brown D, Mindel G, Gleich G. Thrombotic microangiopathy associated with the hypereosinophilic syndrome. Kidney Int. 2005; 67:1806-11. [PubMed: 15840027]

69. Kanno H, Ouchi N, Sato M, Wada T, Sawai T. Hypereosinophilia with systemic thrombophlebitis. Hum Pathol. 2005; 36:585-9. [PubMed: 15948128]

70. Vazquez JJ, Fernandez Pavon A, Arnalich F, et al. Coagulation abnormalities in patients with eosinophilia. Postgrad Med J. 1987; 63:943-5. [PubMed: 3451215]

71. Venge P, Zetterstrom O, Dahl R, Roxin LE, Olsson I. Low levels of eosinophil cationic proteins in patients with asthma. Lancet. 1977; 2:373-5. [PubMed: 70587]

72. Rohrbach MS, Wheatley CL, Slifman NR, Gleich GJ. Activation of platelets by eosinophil granule proteins. J Exp Med. 1990; 172:1271-4. [PubMed: 2212954]

73. Slungaard A, Vercellotti GM, Tran T, Gleich GJ, Key NS. Eosinophil cationic granule proteins impair thrombomodulin function. A potential mechanism for thromboembolism in hypereosinophilic heart disease. J Clin Invest. 1993; 91:1721-30. [PubMed: 8386194]

74. Samoszuk M, Corwin M, Hazen SL. Effects of human mast cell tryptase and eosinophil granule proteins on the kinetics of blood clotting. Am J Hematol. 2003; 73:18-25. [PubMed: 12701115]

75. Wang JG, Mahmud SA, Thompson JA, Geng JG, Key NS, Slungaard A. The principal eosinophil peroxidase product, HOSCN, is a uniquely potent phagocyte oxidant inducer of endothelial cell tissue factor activity: a potential mechanism for thrombosis in eosinophilic inflammatory states. Blood. 2006; 107:558-65. [PubMed: 16166591]

76. Moosbauer C, Morgenstern E, Cuvelier SL, et al. Eosinophils are a major intravascular location for tissue factor storage and exposure. Blood. 2007; 109:995-1002. [PubMed: 17003379]

77. Akuthota P, Xenakis JJ, Weller PF. Eosinophils: offenders or general bystanders in allergic airway disease and pulmonary immunity? J Innate Immun. 2011; 3:113-9. [PubMed: 21228563]

78. Kita H. Eosinophils: multifaceted biological properties and roles in health and disease. Immunol Rev. 2011; 242:161-77. [PubMed: 21682744]

79. Spencer LA, Szela CT, Perez SA, et al. Human eosinophils constitutively express multiple Th1, $\mathrm{Th} 2$, and immuno-regulatory cytokines that are secreted rapidly and differentially. J Leukoc Biol. 2009; 85:117-23. [PubMed: 18840671]

80. Roth N, Stadler S, Lemann M, et al. Distinct eosinophil cytokine expression patterns in skin diseases - the possible existence of functionally different eosinophil sub-populations. Allergy. 2011; 66:1477-86. [PubMed: 21884530]

81. Johnsson M, Bove M, Bergquist H, et al. Distinctive blood eosinophilic phenotypes and cytokine patterns in eosinophilic esophagitis, inflammatory bowel disease and airway allergy. J Innate Immun. 2011; 3:594-604. [PubMed: 21921589]

82. Wang HB, Ghiran I, Matthaei K, Weller PF. Airway eosinophils: allergic inflammation recruited professional antigen-presenting cells. J Immunol. 2007; 179:7585-92. [PubMed: 18025204]

83. Foster EL, Simpson EL, Fredrikson LJ, et al. Eosinophils increase neuron branching in human and murine skin and in vitro. PLoS One. 2011; 6:e22029. [PubMed: 21811556]

84. Verbout NG, Jacoby DB, Gleich GJ, Fryer AD. Atropine-enhanced, antigen challenge-induced airway hyperreactivity in guinea pigs is mediated by eosinophils and nerve growth factor. Am J Physiol Lung Cell Mol Physiol. 2009; 297:L228-37. [PubMed: 19447892] 


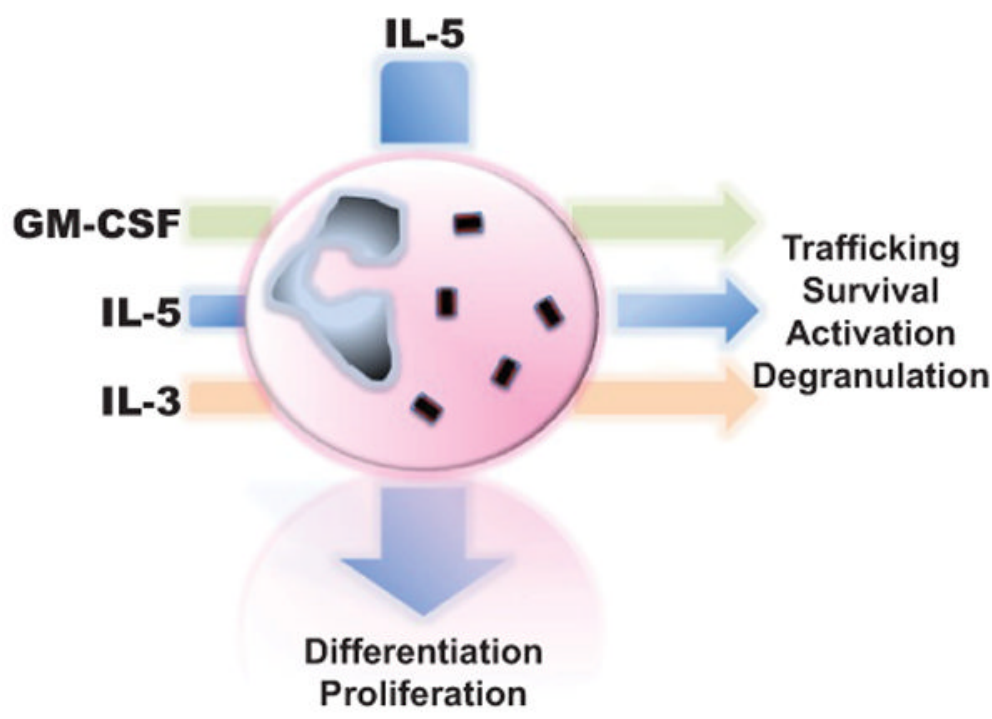

Figure 1.

The effect of major stimulatory cytokines on eosinophils. IL-5, GM-CSF, and IL-3 have wide-ranging effects on eosinophils. IL-5 promotes eosinophil differentiation and proliferation. IL-5, GM-CSF, and IL-3 all have important effects on trafficking, survival, degranulation, and activation of eosinophils. 


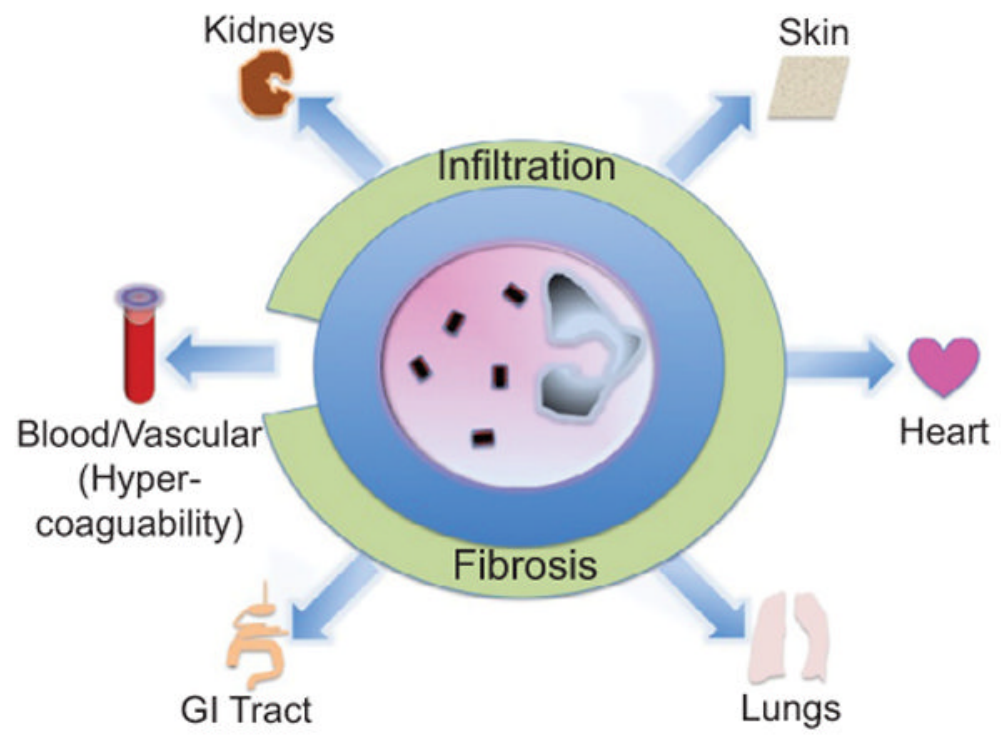

Figure 2.

Organs involved in tissue eosinophilia. As depicted, eosinophils have the potential to infiltrate most organ systems and cause disease. Tissue eosinophilia may lead to end-organ fibrosis. Hypereosinophilia is associated with hypercoagulability. 